\title{
STRATEGY OF POLITICAL PARTY CAMPAIGN ON SOCIAL MEDIA (Case Study of Partai Soldaritas Indonesia in Criticizing the Indonesian Parliament Through YouTube)
}

\author{
Sukma Alam \\ Universitas Budi Luhur, Indonesia. \\ sukma.alam@budiluhur.ac.id
}

\begin{abstract}
This research will examine a case study of PSI's political campaign strategy. The focus of this study is PSI criticizing the performance of the Indonesian Parliament through YouTube. The indication of criticism is a negative campaign carried out by PSI, starting to share information in the form of the performance of the Indonesian Parliament for the 2014-2019 period, among them skipping over plenary meetings, recess funds not transparent to the public and the law-making that takes years to process. This study aims to determine the campaign strategy carried out by PSI in criticizing the Indonesian Parliament through YouTube. And to find out what factors are behind PSI's use of negative campaigns via YouTube. The paradigm of this research is constructivism. The method used in this research is a case study by interviewing key informants and informants. The results of this study indicates that PSI has succeeded in attracting public's attention by criticizing the Indonesian Parliament through YouTube. But the campaign carried out by PSI was not able to attract attention to the real world, PSI's criticism of the Indonesian Parliament was only "strong" on YouTube. In addition, the negative campaign carried out by PSI was motivated by PSI's desire to provide political education and to show that the performance of the Indonesian Parliament is far from public's expectations.
\end{abstract}

Keywords: Social Media, Political Campaigns, PSI

\section{INTRODUCTION}

Nowadays, social media has a very important role in our community, especially in the role of communication. This can be seen by how the developing and developed countries use social media as a political campaign tool. Social media is being utilized by political parties for political purposes, because this media has the power to influence a wide range of audience. This new media is also effective in helping political parties in doing their political campaigns. Social media is different from mass media, because the communication characteristics on social media have interaction and feedback. This era is changing the perspectives of political parties, organizations, and even governments about their political agenda. Initially social media was used by people to talk to their friends, families, and close relatives to share information quickly. There's a shifting of social media trends as a tool of interaction and promotion used by political parties to the public.

Elections are manifestations of democracy where as citizens have the right to elect their leaders at the district or city, provincial and national levels to be in the executive and legislative levels. Each political party has a different way of gaining public's support. At least the principal of the political campaign is to change cognitive, attitude, and behaviour (Heryanto \& Rumaru, 2013: 23-24).

Legislative elections will be held April 17, 2019. Political campaigns are not only used a promotional purpose to introduce the candidates, but are also used to attack opponents through the formation of public opinion. This is often done by political parties or candidates in the General Election and Pileg to overthrow other candidates. Black campaign is prohibited because it leads to defamation, racial intolerance, and fake news.

Black and negative campaigns often become the ultimate choice, but are veiled because the candidates may be involved or carried out by political opponents (Wahid, 2016: 166). Black campaign is a campaign full of efamation and lies about the political opponents. Negative campaigns are campaigns that have negative news content or factual weaknesses of the political opponents. Negative campaigns are not prohibited and are not punished because they are based on facts. What can be punished is a black campaign (https://www.asumsi.co/post/mengupas-perbedaan-kampanye-negatif-dan-kampanye-hitam).

One form of negative campaigs carried out by political parties is the Indonesian Soldaritas Party (PSI) through social media, YouTube. PSI as a new political party using YouTube requires serious efforts to pass the parliamentary threshold to gain support among social media users. 
Since the 2019 legislative election campaign began, PSI has actively used YouTube to criticize the Indonesian Parliament. Starting to disseminate information on the performance of the Indonesian Parliament for the 20142019 period, including completing plenary meetings, recess funds not transparent to the public, and the lawmaking takes years to process.

PSI also dismantled the Indonesian Parliament's activities abroad which squandered the State Budget. PSI used YouTube as its political communication for the need to communicate massively, low cost, and on target. As we know that PSI is a new party and has no bad track record in the past. That's what they want to convey to the public.

This study examines PSI's political campaign strategy in the 2019 legislative elections. Political campaign strategies have principles, one of which is positioning, branding, and segmenting. It is important to point out in this connection that the formulation, planning, and campaign strategy absolutely requires an understanding that marks the situation and behavior of the voting audience (Heryanto, 2018: 93).

PSI which is the subject of this research is able to show the audience's attention in political campaigns. Most political parties when campaigning are only selling off promises. But it's different with what PSI did which criticizing the Indonesian Parliament. PSI established itself as a party that sides with the people. However, different political products and images are needed in political positioning (Heryanto, 2018: 24).

Political branding emphasizes on product's identity. In the political context, branding is a strategy to develop an identity to attract the attention and interest of the community so that they are more familiar with political products (Heryanto, 2018: 95). As a new political party, PSI has big difference from the other political parties about the management and regeneration tha's filled of youth generation who have energetic and intelligent characteristics. PSI appears as a party that focuses on anti-corruption which considered as a campaign strategy that is able to attract the attention of its segmenting among youth and swing voters.

This phenomenon is interesting for researcher to examine political campaign strategies. The phenomenon of changing political campaigns becomes interesting to be further researched. The focus of this research study is to describe the political campaign strategy carried out by PSI via YouTube. The reason the researcher chose PSI's YouTube account was because it has the most subscriptions or other subscriptions among other parties, as many as 40,511 were accessed on Sunday, February 3, 2019.

This study discusses the campaign strategy carried out by PSI in criticizing the Indonesian Parliament through YouTube and what factors are behind PSI's use of negative campaigns.

\section{THEORETICAL FRAMEWORK}

\section{Political Communication}

Political communication is communication involving political messages and political actors or relating to power, government, and government policy (Wahid, 2016: 12). Political communication is concerned with how to explain the political process from the perspective of communication. The essence of political communication is communication directed at achieving an influence in such a way that problems discussed by these types of communication activities can bind a certain group or citizen (Heriyanto \& Rumaru, 2013: 3). According to political expert, Maswadi Rauf, political communication is the study object of political science because the messages expressed in the communication process are characterized by politics that is related to the political power of the state, government, and also the communicator's activity in their position as the agent of political activity (Pureklolon, 2016: 3).

Political parties or political actors use mass media such as print media, electronic media or new media or the Internet in conducting political communication. They use mass media very effectively to convey their political message. Because political communication using mass media plays an important role as the delivery of messages. This process takes place at all levels of society and in every place that allows the exchange of information between individuals and groups (Wahid, 2016: 14).

\section{Political Campaign Strategy}

Campaign strategy is a thinking principle developed to achieve campaign objectives that are usually translated into various tactical steps based on situations and field conditions (Heryanto \& Rumaru, 2013: 34). Political campaign is the process of transforming information in various forms of political messages to audiences with certain communication channels and media influencing and creating public opinion (Wahid, 2012: 113). So a political campaign strategy is a tactic or a way for political parties or politicians to fight over and maintain power in the form of messages by using media that seeks to influence a wide audience. 
Each political party or political actor has a different campaign strategy in getting votes from the public. There are several points that have received serious attention in political campaign strategies in Dr. Gun Gun Heryanto's book, "Political Communication Media", the following are:

\section{Positioning}

The concept of positioning, political parties must be able to position political products and political images in the minds of the people. Because all political parties have the same characteristics. Firmanzah said, political parties must become the domain in controlling the minds of the people by highlighting different political products and images (Firmanzah, 2008: 190-191). However, the main obstacle to make a position is when presidential, legislative, regional head candidates and so on, are very closely related to their past problems. Because people are well aware of the candidate's reputation.

\section{Branding}

Branding in the context of political marketing, is more of a strategic way to develop an identity to attract public's interests so that they are more familiar with political products. Philip Kotler identified the meaning of branding as follows:

a. Atrtibutes: Brands should be able to carry excellence, privilege, quality or strength.

b. Benefits: These features, advantages, and strengths must be translated into emotional and functional benefits.

c. Valus: Brands should also be able to say something about their values or rather the producers have an advantage about their products.

d. Culture: Brands should also present certain cultures.

e. Personality: Brands should also be able to project certain personalities.

f. User: The brand should also be able to touch the facts about who the customer really is (Kotler, 2000: 404-405)

\section{Segmenting}

In campaign, identifying segmentation is very important to capture potential voters, loyalists, political party ideology, constituents and sympathizers. If it has been segmented, then political parties or political actors need to approach the community based on the characteristics of voters. Then segmentation can be identified by using several approaches, including, demography, geography, psychography, behavior, socio-culture and cause-effect (Firmanzah, 2008:186).

Demographic segmentation is a society that is categorized as age, gender, number of members in the household, family life cycle, work, education, religion, ethnicity, income, and nationality. Because in a society has a diversity of knowledge, especially political issues. So the communicator must be careful in communicating to the public so that the message delivered is right on target.

Geographical segmentation is driven by different regional units or regions such as countries, provinces, districts and cities. So in taking a political issue has a different tendency for people living in villages and cities. Psychographic segmentation is the difference in social class, lifestyle and personality. So political communicators must be good at adapting to the public because political behavior will have an impact on voter behavior. Socio-culture segmentation on community identity and environment.

While the process of political campaigns in new media can be developed in a number of understandings aimed at changing the paradigm of political campaigns, including:

1. Political campaigns are joint efforts that support each other to gain trust as well as power.

2. Change understanding and treat audiences as partners, not just political targets.

3. Do not give false promises, but build shared hopes and ideals.

4. Not intimidating in the hope of being in power.

5. Audiences are not mere political targets. Political campaigns are a part of political marketing that must be done seriously and continuously (Wahid, 2016: 172).

\section{Negative Campaign}

We often see negative campaigns in the presidential, regional head, and legislative elections. Roger and Storey define the campaign as "a series of planned communication actions with the aim of creating a certain effect on a large number of sustainable actions (Venus, 2004:7). Meanwhile, negative words from the online version of the dictionary are not good. 
It can be concluded that a negative campaign is an act of communication carried out by political parties or candidates by raising the weaknesses of political opponents with facts and data. A negative campaign is directed by one party to another to give a bad label. Even negative campaigns are done blatantly.

\section{METHODS OF RESEARCH}

The research method used in this research is a case study using a qualitative approach. According to Kriyantono (2006:65), case study research has various methods namely, researching, describing and comprehensively explaining various aspects of individuals, groups, a program, organization, or event in a systematic way. Kriyantono added, data collection instruments used in-depth interviews, participant observation, documentation, recordings and others. Subjects studied were Halimah (Coordinator of PSI Social Media) as key informant and Gun Gun Heryanto (Political Communication Expert) as informant.

\section{THE RESULT OF RESEARCH PSI Campaign Strategy in Criticizing the Indonesian Parliament through YouTube}

Based on the data that researcher obtained from interviews of several sources and literature studies, stated that PSI's campaign strategy in criticizing the the Indonesian Parliament through YouTube has the function of attracting public's attention, especially youth, swing voters in big cities. All strategies including positioning, branding, and segmenting have an impact on political education.

For us, politics, if we do the electability calculations, the political work will be ignored. In our opinion, the task of political parties is to educate constituents. The task of the political party is to educate the youth generation that what is wrong is wrong. It is our right to criticize, and if that affects electability, it is our second and third consideration. The first is to carry out our function as a true political party than other parties (Interview from Halimah).

However, observations made by researcher, PSI's campaign in criticizing the Indonesian Parliament through YouTube provides political education to the public. Therefor, this study describes the political campaign strategy used by PSI:

First, political positioning. This relates to the political image, political products and political messages that distinguish PSI's identity as a newcomer party. So that the image of PSI emerged as a new party with youth in charge. This position is very beneficial for PSI because so far all the political parties seem to have a gap between them and the public. Through a series of criticisms and political messages, PSI seems to have no burden in terms of criticizing the Indonesian Parliament for the 2014-2019 period.

The political position chosen by PSI is fairly bold in representing the people's voice. This is what distinguishes PSI from other parties. That image can be said to be in accordance with political parties that are not in favor of the interests of groups, but are pro to the public.

Second, PSI's political branding during political campaign in the 2019 legislative elections through made modern politics filled with young people.

a. Attributes: PSI uses red jacket to look relaxed, friendly, and egalitarian.

b. Benefits: PSI's treadmark in management and regeneration of youth generation who has fresh and convincing image to the public.

c. Values: PSI carries the slogan "Terbuka, Progressif, Itu Kita!" which then applied to its political message through YouTube.

d. Culture: The culture formed by PSI through YouTube refers to the modern party. Means, the culture of the party brings the attitude, thinking, and acting according to the current era or the term is called "Partai Zaman Now".

e. Personality: Youth who have energetic, intelligent, and egalitarian characters.

f. User: PSI adapts politics to technology that transforms parties as multi-platform.

PSI is portrayed as a new party and youth who have energetic and intelligent characteristics. That branding leads to differentiation when compared to other political parties. PSI carries a different message, so its branding is easily known to the public.

Third, segmentation. Youth and swing voters are the target of PSI segmentation on YouTube. Because youth have the largest number of votes in Indonesia compared to their predecessor generation. Also youth are very close to social media, they consume information everyday through social media. While the swing voters are still hesitant to make their choice in the 2019 legislative elections. The focus of the area that PSI was aiming are 
large cities with internet access. So people who is technologically advanced who want to interact directly with the candidates and people who want to voice their opinion.

\section{PSI's Negative Campaign via YouTube}

PSI, which is a newcomer party, was one of the surprises in the 2019 legislative elections. In politics, a negative campaign is a fact-based and data-based campaign aimed at cornering opponents. What PSI did criticizing the Indonesian Parliament through YouTube was a negative campaign. Of course behind the campaign there are goals and objectives. The following will discuss some of the factors behind PSI's negative campaign through YouTube, based on an analysis of data obtained by researcher.

First, PSI criticizes the Indonesian Parliament not only to increase their electability and increase popularity, but rather to provide political education. This is what distinguishes PSI from other parties, not only giving promises but also making the public more critical and intelligent in seeing political parties.

If you see PSI social media, the contents don't always ask people to choose us, never. We always try to educate and provide alternatives and all the PSI contents are truly educative even not only about politics but also health. So, in addition to political parties, we really want to be a political party that must educate the society (Interview from Halimah).

Secondly, PSI criticized the worst performance of the Indonesian Parliament for the 2014-2019 period because the bill did not meet the target, this was based on data from Formappi (https://tirto.id/formappi-sebut-kinerjadpr-saat-ini-terburuk-sejak-reformasi-reformasi- dapt). In addition, PSI criticized the recess and foreign visit funds that were not transparent and could not be justified. Therefore, PSI in its negative campaign also tried to convince the public that PSI was able to make changes in the Indonesian Parliament system which was originally conventionally into online.

Everything that is brought to the public is all based on data. We want to start a new tradition in politics from transportation alone that has changed from conventional to online. Food supply has changed from people who needs to eat to people who takes photos on social media, the needs is growing, the industry is growing. The only thing that has not developed is Indonesian politics so (Interview from Halimah).

Based on the explanation above, the factors underlying PSI to carry out negative campaigns through YouTube are political education to make the public become smart and critical and to show that the Indonesian Parliament is poor performance.

\section{CONCLUSION}

Based on the analysis of this research, it is concluded that PSI's campaign in criticizing the Indonesian Parliament via YouTube was to attract the public's attention. First is positioning, PSI positions itself as a party that is pro-society. By criticizing the Indonesian Parliament, it proves PSI is not in the political elite side, so criticizing is not based on group interests. This position is very beneficial for PSI because so far there seems to have a gap between political parties and society. Second, branding. PSI is portrayed as a new party consists of youth who have energetic and intelligent characteristics. Its branding leads to differentiation when compared to other political parties. PSI tries to create awareness that its candidates are better than the members of the Indonesian Parliament 2019-2024. Third, PSI segmentation is youth generation and swing voters. Because youth have the largest number of votes in Indonesia and also has the access to information through social media. Meanwhile the swing voters are still hesitant to make their choice in the 2019 legislative elections. PSI seeks to inform that their candidates are better than members of the Indonesian Parliament 2019-2024.

Based on this description shows that PSI managed to attract the attention of the audience by criticizing the Indonesian Parliament via YouTube. But the campaign carried out by PSI was not able to attract attention to the real world, PSI's criticism of the Indonesian Parliament was only strong via YouTube.

PSI hasn't conduct a campaign. The implications have not yet been successful, so what happened at social media was like Obama used to be crowded with social media in the real world. Social media and mainstream media are led to vote. So I see less how to ensure it gets crowded offline. Events to the community are still limited to certain segments and social media has not directed the grab to be truly militant (Interview from Gun Gun Heryanto).

he factor behind PSI's criticism of the Indonesian Parliament through YouTube is that PSI criticizes the Indonesian Parliament not only to increase its electability and popularity, but to provide political education to the public. Then PSI criticized the performance of the Indonesian Parliament for not meeting targets and not being transparent such as funding for visits to voter areas and foreign visits. 


\section{REFERENCE}

Firmanzah. 2004. Marketing Politik: Antara Pemahaman dan Realitas. Jakarta. Yayasan Pustaka Obor Indonesia.

Heryanto, Gun Gun \& Zarkasy, Irwa. 2012. Public Relations politik. Jakarta. Ghalia Indonesia.

Heryanto, Gun Gun. 2018. Media Komunikasi Politik Relasi Kuasa Media di Panggung Politik. Jakarta. IRCiSoD

Kotler, Philip. 2000. Marketing Management The Millennium Edition. New Jersey. Prentice Hall International.

Kriyantono, Rachmat. 2006. Teknik Praktis Riset Komunikasi. Jakarta. Kencana Prenada Media Goup.

Pureklolon, T. T. Komunikasi Politik Mempertahankan Integritas Akademisi, Politikus, dan Negarawan. 2016. Jakarta. PT Gramedia Pustaka Utama.

Venus, Antar. 2004. Manajemen Kampanye: Panduan Teoritis dan Praktis dalam Mengefektifkan Kampanye Komunikasi. Bandung: Simbiosa Rekatama Media

Wahid, Umaimah. 2012. Komunikasi Politik Perkembangan Teori dan Praktik. Bekasi. CV Widaya Media Komunika.

2016. Komunikasi Politik Teori, Konsep, dan Aplikasi Pada Era Media Baru. Bandung. PT Remaja Rosdakarya

\section{INTERNET}

https://www.asumsi.co/post/mengupas-perbedaan-kampanye-negatif-dan-kampanye-hitam

https://www.YouTube.com/channel/UCY2kkUWxtRKoW_qopjGGAtw/videos

\section{INTERVIEW}

Interview with Halimah (PSI Social Media Coordinator) at the Central Office, Central Jakarta on Tuesday, July $16,2019$.

Interview with Dr. Gun Gun Heryanto, M.Si (Political Communication Expert) at the State Islamic University of Syarif Hidayatullah, South Tangerang on Friday, July 26, 2019. 